\title{
Socially Mobile Daughters and Sons of the Elderly: Mobility Effects Within the Family Revisited
}

\author{
STEPHEN KULIS \\ Arizona State University
}

\begin{abstract}
This study examines the effects of intergenerational occupational mobility on relationships between elderly parents and their adult children, using a geographically restricted random sample of parents and a derivative sample of their children. Several explanations for the existence of mobility effects are distinguished and empirically tested: that mobility introduces cultural disparities, invidious status comparisons, or greater residential separation between mobile children and their parents. Survey data from a paired sample of older parents and one of their children indicate that mobility effects depend on the direction of mobility, the gender of the child, and the perspective of the reporting generation, and are limited to feelings and perceptions more than behavior.
\end{abstract}

What happens to family relationships throughout the life span as the socioeconomic fortunes of parents and children diverge? In recent decades family sociologists have consistently reported that intergenerational occupational mobility does not appreciably influence the course of parent-child relations (Adams, 1970; Aiken and Goldberg, 1969; Kessin, 1971; Klatzky, 1972; Lee, 1980; Troll, Miller, and Atchley, 1979). The near consensus of opinion has been challenged on methodological grounds, with criticism of the use of Duncan's (1966) square additive model to test for mobility effects (Halaby and Sobel, 1979; Hope, 1975; Sobel, 1981, 1984), but the possible effects of social mobility on family interactions have not

Funds provided by the National Institute on Aging (Grant No. R01AG00564) and the National Institute of Mental Health (Grant No. R01MH30726) permitted the collection of the data presented in this paper. Fellowship support from the Brookdale Institute on Aging and Adult Human Development at Columbia University supported the initial analysis. The critical advice of Mary Benin and anonymous reviewers is gratefully acknowledged.

Department of Sociology, Arizona State University, Tempe, AZ 85287. been reexamined through alternative procedures. This study reopens the question of mobility effects on intergenerational solidarity by addressing the methodological problems and by focusing on intergenerational relations at the later end of the life span, a period that has not been separately examined in previous studies.

\section{VARIETIES OF MOBILITY EFFECTS THEORY}

There are substantive as well as methodological reasons for resurrecting this nearly dormant topic. Social mobility has been alleged to influence family life for a variety of quite different reasons, yet the several distinct hypotheses have not been tested separately in prior studies. The dominant view has been that mobility is detrimental to family solidarity, but the lines of argument are spun in several varieties from a theoretical thread reaching back through Parsons (1959), Blau (1956), Schneider and Homans (1955), Locke (1940), Davis (1940), and Sorokin (1927), perhaps to Durkheim (1897/1951).

Durkheim's legacy appears in the argument that interactions between socially mobile children and their parents are undermined as the children are assimilated into new reference groups and subcultural patterns more in step with their socioeconomic destinations than their origins. 
The resocialization of the mobile, in other words, weakens bonds through cultural malintegration. Incompatibility and conflict between mobile children and their parents arise from their placement in different social, rather than purely economic, classes. Their diverging socioeconomic statuses reinforce disparities in styles of consumption and in family norms.

Another approach holds that mobility disrupts family ties by introducing invidious comparisons of occupational prestige, or by creating situations of status inconsistency. The upwardly mobile may avoid associations with their humbler origins, and the downwardly mobile may be shunned by their embarrassed or disappointed kin. The motivation of higher-status relatives seems clear here, but not that of their humbler relations. If motivations are grounded above all in a desire to enhance personal status, the aversion of the status-superior may coincide with the intensified attraction of the status-inferior. The latter may attempt to participate vicariously in their relatives' more exalted social position and try to cultivate a close continuing affiliation. Downwardly mobile children who look to parents to sustain their identification with a lost socioeconomic rank may increase the parents' desire to disengage themselves from the children's inferior achievements. Parents who try to "live through" the successes of their upwardly mobile children may intensify the children's anxiety regarding their socioeconomic origins.

A final prediction is reminiscent of Dumont's (1890) observation that small families, like narrower columns of water ascending through capillary action, have better prospects for social mobility. Parsons (1959) contended that nuclear families must be free to move geographically about through the labor market and cannot move all of their relatives along with them. In this line of reasoning the disruptive effects of social mobility are largely the indirect or concomitant results of geographic mobility. Distance can still be bridged, but the necessity of traversing or overcoming it removes family members from intimate daily interaction, enhances the element of discretion in kinship relations, and may inhibit the maintenance of close and diffuse ties.

One limitation of past studies of mobility effects within the family is that while all of these explanations have been entertained at some time, even simultaneously, there has been little effort to discriminate empirically among the explanations. The explanation that attributes social mobility effects to concomitant geographic mobility can be tested by controlling for the distance that separates family members. The two remaining explanations lead to contradictory predictions. If social mobility generates cultural incompatibilities within the family, both the socially mobile and their kin will perceive their relationship as problematic. If, on the other hand, social mobility leads to invidious status comparisons, higherstatus family members will protect or preserve their social status by distancing themselves from lower-status family members, while the latter will enhance their social status by identifying themselves with their status superiors.

\section{LIFE COURSE CONSIDERATIONS}

Dozens of prior studies of mobility effects have focused on selective parts of the life span. Much attention has been given to young adult children and their middle-aged parents. But the effects of the children's social mobility may vary depending upon whether the children are starting their careers, establishing their own households and families, or sending their own children off to college. The dynamics of parent-child interdependence vary across the life course, and the presence or absence of mobility effects may depend on whether the parents are helping their socially mobile children get started in careers and families, or whether the parents themselves face retirement, illness, and the death of a spouse-situations where they may require special financial, emotional, or personal assistance from their children.

Parents move into old age after a prolonged period of relative autonomy between themselves and their adult children. Up to this point, particularly for the middle class, their relationships have bridged separate and financially autonomous households with occasional supplementary household and child care assistance, with gifts and discretionary emotional support. The prospect of reviving or reversing a dependency relationship is resisted by both the elderly and their children (Clark and Anderson, 1967; Simos, 1970), and the threat of violating norms of autonomy may be felt quite acutely by the socially mobile and their parents, particularly if they have adjusted over several decades to the socioeconomic, cultural, and geographic distances that separate them.

A variety of adjustments may occur if these "distances" begin to close at the end of the parent's life span. The parent's declining physical abilities may require more taxing forms of help from the child. Differences in styles of living may be brought into closer and more frequent contact. Cultural divergences between the mobile and their parents cannot be as easily managed by making interactions brief, by confining them to leisure time, or by conducting them indirectly by telephone over great distances. It is possible for interdependence between the parents' and children's 
households to become more extensive than ever before in their adult experience. Households may even merge. If the attraction of the generations for one another is impaired by invidious status comparisons, upwardly mobile children may find the new demands for interdependence particularly irksome. These children may be more reluctant to assume enlarged responsibility for their parents, and they may become more resentful of the additional help they do provide.

\section{METHOD}

Mobility effects were examined with the use of data collected in 1978 in the New York City and Miami-Fort Lauderdale metropolitan areas. Interviews were conducted with a probability sample of those 65 and older in these areas, stratified to include approximately equal numbers of respondents from working- and middle-class neighborhoods, and from age-concentrated $(30 \%$ or more elderly) and less concentrated neighborhoods. The findings here are based on a subsample of noninstitutionalized older parents with at least one living child. These parents described their relationships with one of their children: their patterns of mutual exchange and assistance; their feelings of affection, attachment, and resentment toward the child; their frequency of telephoning, visiting, and joint leisure pursuits; and their perception of lifestyle similarities with their children.

In addition to the parent interviews, telephone interviews were subsequently conducted with a sample of the children discussed by the parents. These children were asked questions that paralleled those asked of the parents, which permitted us to contrast parent and child perceptions of intergenerational relations. For reports of the parent's views, we utilize the full random sample of elderly parents; for the child's views, we employ the smaller derivative sample of the adult children of the elderly respondents. The response rate in the parent sample was $60 \%$. Of the children identified by the parents, $55 \%$ were interviewed.'

This is a random sample of parents, but not of their children. These data were collected for a study that focused on the caregivers of the elderly (Litwak, 1985), and in naming a child, parents were instructed to select from among their children the child who helped them the most. Complete matched pairs of parent and child were more likely to be interviewed if the child identified by the parent was a daughter, lived nearby, or regularly helped the parent at home, and if the parent was a mother, saw the child daily, or regarded the child with particular affection. From the parent's point of view the sample perhaps focuses on the most dutiful child. Although these children appear to be especially involved with their parents, it is not clear that they are more positively or negatively oriented toward their parents than a completely random sample of children of the elderly.

\section{MODELING FOR MOBILITY EFFECTS}

Duncan's (1961) index of socioeconomic position (SEI) is used here to determine the degree and direction of intergenerational social mobility by contrasting parent and child scores. ${ }^{2}$ Both parents and children are assigned the SEI scores of the spouse they designated as the main breadwinner in their families. For parents this is the SEI score for the last job before retirement. In cases where both husband and wife were named as equal breadwinners, the higher SEI score has been assigned.

Several models have been employed to test for the distinctive effects of social mobility on family relations. ${ }^{3}$ A controversy over appropriate modeling has occupied center stage in studies of mobility effects in recent years. The main issue is how to account simultaneously for both class and mobility effects, especially when mobility is, by definition, the difference between class of origin and class of destination. ${ }^{4}$ Duncan (1966) criticized studies that claimed to show mobility effects for not first discounting a "simpler" explanation: that these were the additive effects of class of origin and class of destination. According to Duncan, the null hypothesis in tests of mobility effects should not be that the mobile act like the nonmobile, but that they appear to be acculturated, adopting traits intermediate to those characterizing their strata of origin and destination. But there are also problems with Duncan's model, particularly when upward or downward mobility is prevalent, such that a large portion of those within a given socioeconomic stratum have arrived there through mobility. In this instance, the model estimates the effects of class destinations on predominantly mobile groups, yet assigns the possibly peculiar orientations of the mobile to class rather than mobility effects.

Three solutions to this problem are available. Hope (1975) proposed that class effects should be estimated with one parameter, by averaging an individual's class of origin and class of destination. But this raises undesirable complications if socioeconomic origin and destination do not exert equal influences on attitudes or behavior, or if they exert influences in opposing directions. Sobel (1981) presented a diagonal mobility model, maintaining that the effects of class origins and class destinations should be controlled in the model, but that they should be estimated on the basis of 
the nonmobile cases only. By using these estimates, the effects of class origins and destinations are then accounted for among the mobile and nonmobile alike, leaving only the variation specifically attributable to the presence, extent, or direction of mobility. In essence, the approach here is to control for how the mobile might have acted had they not been mobile, assuming they would act like the nonmobile with similar class origins and destinations.

These latter two models still incorporate Duncan's null hypothesis of acculturation, from which the last approach departs. They each assume that both class origins and destinations are independently influential on the dependent variable and must be incorporated within any model of mobility effects. However, if either class origin or class destination is not, in fact, a significant predictor, the nonsignificant parameter can be dropped from the model if its exclusion does not change the estimates for the remaining variables. This simplifies the task of estimating mobility effects by eliminating the problem of overidentification that arises when all potentially relevant class and mobility parameters are simultaneously included in this model. ${ }^{5}$

In this study, both class of origin (parent's SEI) and class of destination (child's SEI) were significant predictors, nearly equal in magnitude, of only one type of family interaction, that which requires face-to-face contact, such as visiting frequency and "hands on" household assistance. These apparent class effects are, in turn, largely indirect results of the greater residential distances that separate higher-SES family members from one another. For these dependent variables we contrast the estimated mobility effects obtained with the Duncan, Hope, and Sobel models, preferring the latter. For other aspects of family relationships-feelings of affection, sociability, lifestyle similarity, and feelings of sacrifice-only the parent's SEI exerted an independent influence, and we present a single model that excludes the child's SEI. ${ }^{6}$

Operational definitions, means, and standard deviations of all dependent variables appear in Appendix A.

\section{RESULTS}

\section{Visiting Frequency}

The starting point for analysis is an examination of the frequency with which mobile children and their parents visited one another. Table 1 estimates Duncan's square and Hope's diamond additive models, along with a multiple regression model analogous to Sobel's diagonal model assuming equivalent influences of class of destination and class of origin.' Although the diagonal model may be preferred in principle over the others, in this instance the choice is moot because each of the models indicates that neither the presence, extent, nor direction of occupational mobility significantly predicts how often parents and children visit one another. With the introduction of intergenerational proximity into the model, which accounts for most of the considerable variance explained in these equations, even the class parameters are reduced to insignificance.

As a measure of family interaction, contact frequency is insensitive to the content of interaction, which is clearly crucial in two explanations of how mobility might influence family relationships, through resocialization or through invidious status comparisons. Visiting relates more clearly to the third explanation, that the socially mobile may interact less with their parents because they live farther away from them than the nonmobile. Nevertheless, results not presented here indicate that mobility remains irrelevant to visiting frequency when the additional predictors-intergenerational proximity, disability, marital status, and gender-are removed from the model. Thus, although residential separation is a powerful determinant of visiting frequency, it is not, in turn, significantly determined by social mobility, as Table 2 demonstrates.

\section{Service and Sacrifice}

One could contend that another measure of family interaction relates to all three explanations of mobility effects: direct services provided by the child to the parent. Cultural disparities between mobile children and their parents could lead to greater reluctance to become involved in the dayto-day operations of the parent's household, because differences in scheduling and in expectations about household management might be brought into conflict. At the same time, status comparisons might discourage parents from requesting, and mobile children from offering, such assistance. Finally, greater distances between the socially mobile and their parents might impede their ability to provide these services.

In Table 3, however, mobility is shown to be an insignificant factor in the provision of household services to the parent, and the overwhelming influence of proximity is again demonstrated. Social mobility does not deter or discourage children from assisting their elderly parents. But might it affect the spirit in which such assistance is offered? The uniquely potent and enduring nature of parent-child bonds may ensure that children 
TABLE 1. Regression of Parent-Child Visiting Frequency $(\mathrm{N}=855)$

\begin{tabular}{|c|c|c|c|}
\hline Predictor Variables & $\begin{array}{c}\text { Square Additive } \\
\text { Model }\end{array}$ & $\begin{array}{c}\text { Diamond Additive } \\
\text { Model }\end{array}$ & $\begin{array}{c}\text { Diagonal } \\
\text { Model }\end{array}$ \\
\hline Parent's SEI & $\begin{array}{l}-.002 \\
(-.018)\end{array}$ & & \\
\hline Child's SEI & $\begin{array}{c}.002 \\
(-0.19)\end{array}$ & & \\
\hline Average of parent's and child's SEI & & $\begin{array}{l}.0003 \\
(.003)\end{array}$ & \\
\hline Extent of mobility & $\begin{array}{l}-.001 \\
(-.012)\end{array}$ & & \\
\hline $\begin{array}{l}\text { Direction of mobility } \\
\text { (upward vs. downward) }\end{array}$ & $\begin{array}{l}-.006 \\
(-.001)\end{array}$ & & \\
\hline Mobility versus stability & $\begin{array}{c}-.022 \\
(-.004)\end{array}$ & & \\
\hline Extent of downward mobility & & $\begin{array}{l}-.004 \\
(-.019)\end{array}$ & $\begin{array}{l}-.002 \\
(-.012)\end{array}$ \\
\hline Extent of upward mobility & & $\begin{array}{l}.0001 \\
(.001)\end{array}$ & $\begin{array}{l}-.001 \\
(-.012)\end{array}$ \\
\hline Residential separation & $\begin{array}{l}-.932^{* * *} \\
(-.833)\end{array}$ & $\begin{array}{l}-.932^{* * *} \\
(-.833)\end{array}$ & $\begin{array}{l}-.890^{* * *} \\
(-.811)\end{array}$ \\
\hline Parental disability & $\begin{array}{l}-.014 \\
(-.017)\end{array}$ & $\begin{array}{l}-.014 \\
(-.017)\end{array}$ & $\begin{array}{l}-.024 \\
(-.030)\end{array}$ \\
\hline Number of parent's living children & $\begin{array}{l}.118^{* * *} \\
(.066)\end{array}$ & $\begin{array}{l}.118^{* * *} \\
(.066)\end{array}$ & $\begin{array}{l}.088^{* *} \\
(.050)\end{array}$ \\
\hline Parent married versus unmarried & $\begin{array}{l}.037 \\
(.008)\end{array}$ & $\begin{array}{l}.037 \\
(.008)\end{array}$ & $\begin{array}{l}-.018 \\
(-.004)\end{array}$ \\
\hline Parent female versus male & $\begin{array}{l}-.044 \\
(-.009)\end{array}$ & $\begin{array}{l}-.044 \\
(-.009)\end{array}$ & $\begin{array}{l}-.032 \\
(-.007)\end{array}$ \\
\hline Child married versus unmarried & $\begin{array}{l}.065 \\
(.012)\end{array}$ & $\begin{array}{l}.064 \\
(.011)\end{array}$ & $\begin{array}{l}.019 \\
(.004)\end{array}$ \\
\hline Child female versus male & $\begin{array}{l}.061 \\
(.013)\end{array}$ & $\begin{array}{c}.061 \\
(.013)\end{array}$ & $\begin{array}{l}.050 \\
(.011)\end{array}$ \\
\hline $\begin{array}{l}\text { Constant } \\
R^{2}\end{array}$ & $\begin{array}{l}5.896 \\
.715\end{array}$ & $\begin{array}{r}5.910 \\
.715\end{array}$ & $\begin{array}{l}7.055 \\
.674 a\end{array}$ \\
\hline
\end{tabular}

Note: Standardized regression coefficients are in parentheses.

aExplained variation in the last step of estimation only.

${ }^{*} p<.01 .{ }^{* *} p<.001$.

respond to their parents' obvious needs, but children may act out of an ambivalent mixture of selflessness, genuine concern, gratitude, love, obligation, and guilt. Among those children helping their parents in identically tangible ways, some may be more reluctant and burdened than others. These mixed sentiments are explored in an examination of the child's report that the help given to a parent entails some measure of sacrifice.

A comparison of the first and second columns of Table 4 reveals that upwardly mobile daughters, but not sons, express a significantly greater sense of sacrifice in assisting their parents. Downward mobility, however, is irrelevant to the sacrifices reported by both sons and daughters. The last two columns of the table refine the hypothesis that the sense of sacrifice of the upwardly mobile increases to the extent that they provide direct services to their parents, introducing an interaction term of assistance by extent of upward mobility. Even when the number of services actually provided are controlled, upwardly mobile daughters report a greater sense of sacrifice only to the extent that they provide help. Conversely, the sheer provision of assistance is not directly related to feelings of sacrifice for daughters generally, but only when it is associated with upward mobility as well. Sons appear to act in a more straightforward manner. Their sense of sacrifice relates to how many services they provide to their parents, but whether they are upwardly or downwardly mobile is irrelevant.

The differences here between sons and daughters may reflect gender roles: sons are more rarely called upon to help parents in this way, and when they are, the assistance they give is felt to be a sacrifice. Daughters do not feel especially burdened simply because they provide help to their parents, but only when they are upwardly mobile as well. Both mobile and nonmobile children ap- 
TABle 2. Regression of Parent-Child Residential Separation $(\mathrm{N}=856)$

\begin{tabular}{|c|c|c|c|}
\hline Predictor Variables & $\begin{array}{l}\text { Square Additive } \\
\text { Model }\end{array}$ & $\begin{array}{c}\text { Diamond Additive } \\
\text { Model }\end{array}$ & $\begin{array}{l}\text { Diagonal } \\
\text { Model }\end{array}$ \\
\hline Parent's SEI & $\begin{array}{l}.005 \\
(.063)\end{array}$ & & \\
\hline Child's SEI & $\begin{array}{l}.017^{* * *} \\
(.180)\end{array}$ & & \\
\hline Average of parent's and child's SEI & & $\begin{array}{l}.023^{* * *} \\
(.201)\end{array}$ & \\
\hline Extent of mobility & $\begin{array}{l}.001 \\
(.007)\end{array}$ & & \\
\hline $\begin{array}{l}\text { Direction of mobility } \\
\text { (upward vs. downward) }\end{array}$ & $\begin{array}{l}-.160 \\
(-.037)\end{array}$ & & \\
\hline Mobility versus stability & $\begin{array}{l}-.305 \\
(-.063)\end{array}$ & & \\
\hline Extent of downward mobility & & $\begin{array}{c}-.007 \\
(-.041)\end{array}$ & $\begin{array}{c}-.005 \\
(-.026)\end{array}$ \\
\hline Extent of upward mobility & & $\begin{array}{l}.001 \\
(.011)\end{array}$ & $\begin{array}{l}-.002 \\
(-.016)\end{array}$ \\
\hline Parental disability & $\begin{array}{l}-.051 * \\
(-.071)\end{array}$ & $\begin{array}{c}-.052^{*} \\
(-.072)\end{array}$ & $\begin{array}{l}-.078 * * \\
(-.101)\end{array}$ \\
\hline Number of parent's living children & $\begin{array}{l}-.273^{* * *} \\
(-.171)\end{array}$ & $\begin{array}{l}-.270^{* * *} \\
(-.169)\end{array}$ & $\begin{array}{l}-.355^{* * *} \\
(-.210)\end{array}$ \\
\hline Parent married versus unmarried & $\begin{array}{l}.410^{* *} \\
(.098)\end{array}$ & $\begin{array}{l}.410^{* *} \\
(.098)\end{array}$ & $\begin{array}{l}.332^{*} \\
(.075)\end{array}$ \\
\hline Parent female versus male & .031 & $\begin{array}{l}.031 \\
(.007)\end{array}$ & $\begin{array}{l}.059 \\
(.013)\end{array}$ \\
\hline Child married versus unmarried & $\begin{array}{l}.873^{* * *} \\
(.179)\end{array}$ & $\begin{array}{l}.867^{* * *} \\
(.178)\end{array}$ & $\begin{array}{l}.849^{* * *} \\
(.165)\end{array}$ \\
\hline Child female versus male & $\begin{array}{l}-.424 * * \\
(-.102)\end{array}$ & $\begin{array}{l}-.426^{* *} \\
(-.102)\end{array}$ & $\begin{array}{l}-.485^{* * *} \\
(-.110)\end{array}$ \\
\hline $\begin{array}{l}\text { Constant } \\
R^{2}\end{array}$ & $\begin{array}{r}2.061 \\
.152 \\
\end{array}$ & $\begin{array}{r}2.290 \\
.149 \\
\end{array}$ & $\begin{array}{r}4.849 \\
.112^{\mathrm{a}} \\
\end{array}$ \\
\hline
\end{tabular}

Note: Standardized regression coefficients are in parentheses.

aExplained variation in the last step of estimation only.

${ }^{*} p<.05 .{ }^{* *} p<.01 .{ }^{* * *} p<.001$.

pear to respond to the pull of filial obligations when their parents begin to need assistance, possibly as a result of declining physical abilities or the loss of a spouse. The mobility effects are confined to how upwardly mobile daughters feel about such assistance.

\section{Sociability and Lifestyle Similarity}

A very different pattern of mobility effects emerges in other areas of intergenerational relations. Table 5 investigates an area that might be less effectively ruled by filial norms, where both parents and children legitimately exercise considerable discretion about their degree of involvement with one another: sociable contacts in leisure time. This time the mobility effects are confined to downwardly mobile sons. The second column of the table indicates that the parents of downwardly mobile sons report these sons to be less involved in sociable activities with the parents: seeing other relatives, eating together, and giving gifts. At the same time, in the fourth column these parents also report that their downwardly mobile sons are less similar to the parents in lifestyle. Although one would surmise that upwardly mobile sons would also be leading divergent styles of living, their parents do not point out any particular lifestyle discrepancies.

Might both of these ways of describing downwardly mobile sons, but not the upwardly mobile, reflect the parents' desire to mark off social distance between themselves and their humbler relations? This speculation is supported by the reciprocal views of the child in the fifth column of Table 5. Here only upwardly mobile children describe their parents as especially dissimilar in lifestyle, not the downwardly mobile. The asymmetries here seem to revolve, in short, around who is "on top." Parents appear to distance themselves, both socially and culturally, from their less successful sons but remain silent on any differences with children more successful than themselves. The children, in turn, report dissimilarities in lifestyle with their lower-status parents 
TABle 3. Regression of the Number of Household Services Provided by Children to Parents $(\mathrm{N}=856)$

\begin{tabular}{|c|c|c|c|}
\hline Predictor Variables & $\begin{array}{c}\text { Square Additive } \\
\text { Model }\end{array}$ & $\begin{array}{c}\text { Diamond Additive } \\
\text { Model }\end{array}$ & $\begin{array}{l}\text { Diagonal } \\
\text { Model }\end{array}$ \\
\hline Parent's SEI & $\begin{array}{l}-.004 \\
(-.074)\end{array}$ & & \\
\hline Child's SEI & $\begin{array}{l}.003 \\
(.041)\end{array}$ & & \\
\hline Average of parent's and child's SEI & & $\begin{array}{l}-.002 \\
(-.020)\end{array}$ & \\
\hline Extent of mobility & $\begin{array}{l}.001 \\
(.014)\end{array}$ & & \\
\hline $\begin{array}{l}\text { Direction of mobility } \\
\text { (upward vs. downward) }\end{array}$ & $\begin{array}{l}-.225 \\
(-.077)\end{array}$ & & \\
\hline Mobility versus stability & $\begin{array}{l}.029 \\
(.009)\end{array}$ & & \\
\hline Extent of downward mobility & & $\begin{array}{l}.003 \\
(.024)\end{array}$ & $\begin{array}{l}.004 \\
(.031)\end{array}$ \\
\hline Extent of upward mobility & & $\begin{array}{l}.003 \\
(.041)\end{array}$ & $\begin{array}{l}.002 \\
(.031)\end{array}$ \\
\hline Residential separation & $\begin{array}{l}-.359 * * * \\
(-.536)\end{array}$ & $\begin{array}{l}-.359^{* * *} \\
(-.534)\end{array}$ & $\begin{array}{l}-.336^{* * *} \\
(-.507)\end{array}$ \\
\hline Parental disability & $\begin{array}{l}.088 * * * \\
(.180)\end{array}$ & $\begin{array}{l}.088^{* * *} \\
(.180)\end{array}$ & $\begin{array}{l}.083^{* * *} \\
(.171)\end{array}$ \\
\hline Number of parent's living children & $\begin{array}{l}.046 \\
(.043)\end{array}$ & $\begin{array}{l}.045 \\
(.042)\end{array}$ & $\begin{array}{l}.029^{* *} \\
(.027)\end{array}$ \\
\hline Parent married versus unmarried & $\begin{array}{l}-.383 * * * \\
(-.137)\end{array}$ & $\begin{array}{l}-.382^{* * *} \\
(-.136)\end{array}$ & $\begin{array}{l}-.412 * * * \\
(-.149)\end{array}$ \\
\hline Parent female versus male & $\begin{array}{l}.227^{* *} \\
(.078)\end{array}$ & $\begin{array}{l}.225^{* *} \\
(.078)\end{array}$ & $\begin{array}{l}.231^{* *} \\
(.081)\end{array}$ \\
\hline Child married versus unmarried & $\begin{array}{l}-.105 \\
(-.032)\end{array}$ & $\begin{array}{c}-.109 \\
(-.033)\end{array}$ & $\begin{array}{l}-.133 \\
(-.041)\end{array}$ \\
\hline Child female versus male & $\begin{array}{l}.019 \\
(.007)\end{array}$ & $\begin{array}{l}.030 \\
(.001)\end{array}$ & $\begin{array}{l}.024 \\
(.009)\end{array}$ \\
\hline $\begin{array}{l}\text { Constant } \\
R^{2}\end{array}$ & $\begin{array}{r}1.938 \\
.435\end{array}$ & $\begin{array}{r}1.997 \\
.433\end{array}$ & $\begin{array}{l}2.619 \\
.395 a\end{array}$ \\
\hline
\end{tabular}

Note: Standardized regression coefficients are in parentheses.

aExplained variation in the last step of estimation only.

${ }^{* *} p<.01 . * * *<.001$.

but do not call attention to the lifestyle gaps that might also be expected when the parents are more occupationally successful than the children. Common to these two findings is the possibility that both parents and children may be sensitive to differences in socioeconomic prestige between one another and attempt to enhance their own personal status when describing their associations with kin of higher or lower status. The status of one may be perceived as a reflection of the other. When the other's status is inferior, they are more apt to distance their own way of life from it; when the other's status is superior, they do not remark upon their inferior position by pointing out lifestyle divergences.

\section{Affection of, and for, Social Skidders}

A final set of findings in Table 6 is once again confined to sons, and is limited to two groups of downwardly mobile sons. In the first two equa- tions children express more or less qualified feelings of affection for their parents. The first equation shows that both class and mobility are unrelated to the expressions of affection of daughters for their elderly parents. The second column indicates, however, that downwardly mobile sons are especially unreserved in their reports of affection toward their parents.

The remaining columns of Table 6 examine the parent's feelings of affection for their children, which are largely invariant. Upward or downward mobility is generally irrelevant to the parent's expressions, except in one quite unusual circumstance. The fourth variable in this model is an interaction term that registers the distinctive feelings of affection of lower-SES parents toward children who have fallen even farther down the socioeconomic ladder. Although a very rare occurrence among current cohorts of the elderly and their children, and a very modest effect, these 
TABle 4. Regression of Child's Sense of Sacrifice as a Provider of Assistance to the Parent

\begin{tabular}{|c|c|c|c|c|}
\hline \multirow[b]{2}{*}{ Predictor Variables } & \multicolumn{2}{|c|}{ Initial Model } & \multicolumn{2}{|c|}{ Interaction Model } \\
\hline & Daughters Only & Sons Only & Daughters Only & Sons Only \\
\hline Parent's SEI & $\begin{array}{l}.001 \\
(.023)\end{array}$ & $\begin{array}{c}-.002 \\
(-.059)\end{array}$ & $\begin{array}{l}.0004 \\
(.011)\end{array}$ & $\begin{array}{c}-.003 \\
(-.076)\end{array}$ \\
\hline Extent of upward mobility & $\begin{array}{l}.007^{*} \\
(.144)\end{array}$ & $\begin{array}{r}-.0001 \\
(-.003)\end{array}$ & $\begin{array}{l}-.0005 \\
(-.010)\end{array}$ & $\begin{array}{l}.001 \\
(.017)\end{array}$ \\
\hline Extent of downward mobility & $\begin{array}{c}-.001 \\
(-.011)\end{array}$ & $\begin{array}{c}-.004 \\
(-.065)\end{array}$ & $\begin{array}{c}-.001 \\
(-.013)\end{array}$ & $\begin{array}{c}-.004 \\
(-.062)\end{array}$ \\
\hline Residential separation & $\begin{array}{c}-.045 \\
(-.107)\end{array}$ & $\begin{array}{c}-.033 \\
(-.086)\end{array}$ & $\begin{array}{c}-.023 \\
(-.054)\end{array}$ & $\begin{array}{l}.032 \\
(.083)\end{array}$ \\
\hline Parental disability & $\begin{array}{l}.086^{* * *} \\
(.287)\end{array}$ & $\begin{array}{l}.047^{*} \\
(.165)\end{array}$ & $\begin{array}{l}.082^{* * *} \\
(.276)\end{array}$ & $\begin{array}{c}.034 \\
(.118)\end{array}$ \\
\hline Number of parent's living children & $\begin{array}{c}-.029 \\
(-.046)\end{array}$ & $\begin{array}{l}.022 \\
(.035)\end{array}$ & $\begin{array}{c}-.031 \\
(-.049)\end{array}$ & $\begin{array}{l}.024 \\
(.039)\end{array}$ \\
\hline Parent married versus unmarried & $\begin{array}{c}-.044 \\
(-.025)\end{array}$ & $\begin{array}{l}.006 \\
(.004)\end{array}$ & $\begin{array}{c}-.043 \\
(-.024)\end{array}$ & $\begin{array}{l}.085 \\
(.054)\end{array}$ \\
\hline Parent female versus male & $\begin{array}{l}.070 \\
(.037)\end{array}$ & $\begin{array}{c}-.017 \\
(-.011)\end{array}$ & $\begin{array}{l}.042 \\
(.022)\end{array}$ & $\begin{array}{c}-.078 \\
(-.049)\end{array}$ \\
\hline Child married versus unmarried & $\begin{array}{l}.117 \\
(.058)\end{array}$ & $\begin{array}{c}-.193 \\
(-.097)\end{array}$ & $\begin{array}{l}.104 \\
(.051)\end{array}$ & $\begin{array}{c}-.159 \\
(-.080)\end{array}$ \\
\hline Number of household services & & & $\begin{array}{l}-.032 \\
(-.056)\end{array}$ & $\begin{array}{l}.232^{* *} \\
(.354)\end{array}$ \\
\hline Household services $\times$ Upward mobility & & & $\begin{array}{l}.004^{* * * *} \\
(.230)\end{array}$ & $\begin{array}{c}-.002 \\
(-.101)\end{array}$ \\
\hline $\begin{array}{l}\text { Constant } \\
R^{2} \\
n\end{array}$ & $\begin{array}{r}1.293 \\
.139 \\
322\end{array}$ & $\begin{array}{r}1.766 \\
.070 \\
193\end{array}$ & $\begin{array}{r}1.349 \\
.167 \\
322\end{array}$ & $\begin{array}{r}1.374 \\
.123 \\
193\end{array}$ \\
\hline
\end{tabular}

Note: Standardized regression coefficients are in parentheses.

${ }^{*} p<.05 .{ }^{* * *} p<.001$.

parents express significantly more qualified feelings of affection toward their downwardly mobile children. A comparison of the third and fourth columns indicates that the parents' more qualified expressions of affection are somewhat more reserved for this atypical group of downwardly mobile sons than for the comparable group of downwardly mobile daughters.

Why would downwardly mobile sons be more unrestrained in expressions of affection for their parents, while some of their parents-those from modest socioeconomic backgrounds-are more restrained in describing their love for the sons? To the extent that expressions of affection are indications of identification with the other, these mobility effects are consistent with the explanation of invidious status comparisons. The downwardly mobile emphasize their bonds to higherstatus parents through expressions of unqualified affection for them, while the parents of some of the downwardly mobile distance themselves from their offspring by registering some reservation in the affection that they return.

Table 7 expands this explanation and points to one reason why parents qualify their feelings of affection for only a small segment of their downwardly mobile children. The table divides the sam- ple into blue-collar and white-collar parents and traces the child's mobility from those origins. Children report here whether they have received emotional support from the parent over the last six months, and any direct household assistance. Two groups of downwardly mobile children are remarkable. Those from blue-collar backgrounds are most likely to say their parents are providing them with household assistance. This is the small group in the regression analyses whose parents report more qualified affection toward the children. The other, larger group of downwardly mobile children come from white-collar backgrounds and are especially likely to name their parents as sources of emotional support. As we have seen, the sons among them also express more unqualified feelings of affection for their parents.

Downward mobility appears to have quite different consequences for family relations, depending on one's socioeconomic background. The vast majority of downwardly mobile sons come from white-collar backgrounds and seem to remain attached to their parents as sources of emotional support, looking upon them with especially unqualified affection. For these children, whitecollar parents may represent a cherished attachment to a socioeconomic world they no longer oc- 
TABle 5. Regression of Number of Parent-Child Sociable Kinship Activities, and Perceptions of Lifestyle SIMILARITY

\begin{tabular}{|c|c|c|c|c|c|}
\hline \multirow[b]{3}{*}{ Predictor Variables } & \multirow{2}{*}{\multicolumn{2}{|c|}{$\begin{array}{c}\text { Sociable Kinship } \\
\text { Activities } \\
\text { Parent's Report }\end{array}$}} & \multicolumn{3}{|c|}{ Perceived Lifestyle Similarity } \\
\hline & & & \multicolumn{2}{|c|}{$\begin{array}{c}\text { Parent's } \\
\text { Report }\end{array}$} & \multirow{2}{*}{$\begin{array}{c}\text { Child's } \\
\text { Report } \\
\text { All } \\
\text { Children }\end{array}$} \\
\hline & $\begin{array}{l}\text { Parents of } \\
\text { Daughters }\end{array}$ & $\begin{array}{l}\text { Parents of } \\
\text { Sons }\end{array}$ & $\begin{array}{l}\text { Parents of } \\
\text { Daughters }\end{array}$ & $\begin{array}{c}\text { Parents of } \\
\text { Sons }\end{array}$ & \\
\hline$\overline{\text { Parent's SEI }}$ & $(.0002)$ & $\begin{array}{c}.001 \\
(.023)\end{array}$ & $\begin{array}{c}-.002 \\
(-.034)\end{array}$ & $\begin{array}{l}.001 \\
(.019\end{array}$ & $\begin{array}{l}-.001 \\
(-.016)\end{array}$ \\
\hline Extent of upward mobility & $\begin{array}{l}.003 \\
(.060)\end{array}$ & $\begin{array}{l}-.003 \\
(-.053)\end{array}$ & $\begin{array}{l}.003 \\
(.062)\end{array}$ & $\begin{array}{l}.0001 \\
(.003)\end{array}$ & $\begin{array}{l}-.006^{*} \\
(-.116)\end{array}$ \\
\hline Extent of downward mobility & $\begin{array}{l}.001 \\
(.014)\end{array}$ & $\begin{array}{l}-.019^{* * *} \\
(-.183)\end{array}$ & $\begin{array}{c}.003 \\
(.034)\end{array}$ & $\begin{array}{l}-.015 * \\
(-.143)\end{array}$ & $\begin{array}{l}-.003 \\
(-.035)\end{array}$ \\
\hline Residential separation & $\begin{array}{l}-.223^{* * * *} \\
(-.407)\end{array}$ & $\begin{array}{l}-.214 * * * \\
(-.376)\end{array}$ & $\begin{array}{l}-.099 * * * \\
(-.187)\end{array}$ & $\begin{array}{l}-.031 \\
(-.055)\end{array}$ & $\begin{array}{l}-.046 \\
(-.092)\end{array}$ \\
\hline Parental disability & $\begin{array}{l}.049^{* *} \\
(.126)\end{array}$ & $\begin{array}{c}.014 \\
(.032)\end{array}$ & $\begin{array}{l}-.061^{* * *} \\
(-.166)\end{array}$ & $\begin{array}{l}.004 \\
(.009)\end{array}$ & $\begin{array}{l}-.016 \\
(-.044)\end{array}$ \\
\hline Number of parent's children & $\begin{array}{l}.072 \\
(.086)\end{array}$ & $\begin{array}{l}.063 \\
(.067)\end{array}$ & $\begin{array}{l}.039 \\
(.048)\end{array}$ & $\begin{array}{l}-.042 \\
(-.045)\end{array}$ & $\begin{array}{l}.010 \\
(.013)\end{array}$ \\
\hline Parent married versus unmarried & $\begin{array}{l}.040 \\
(.017)\end{array}$ & $\begin{array}{l}.008 \\
(.003)\end{array}$ & $\begin{array}{l}.101 \\
(.046)\end{array}$ & $\begin{array}{l}.040 \\
(.018)\end{array}$ & $\begin{array}{l}.121 \\
(.057)\end{array}$ \\
\hline Parent female versus male & $\begin{array}{l}.018 \\
(.008)\end{array}$ & $\begin{array}{l}.142 \\
(.061)\end{array}$ & $\begin{array}{l}.293^{*} \\
(.126)\end{array}$ & $\begin{array}{l}.006 \\
(.003)\end{array}$ & $\begin{array}{l}.012 \\
(.006)\end{array}$ \\
\hline Child married versus unmarried & $\begin{array}{l}.130 \\
(.051)\end{array}$ & $\begin{array}{l}.095 \\
(.033)\end{array}$ & $\begin{array}{l}.186 \\
(.075)\end{array}$ & $\begin{array}{l}.259 \\
(.092)\end{array}$ & $\begin{array}{l}.088 \\
(.035)\end{array}$ \\
\hline Child female versus male & & & & & $\begin{array}{l}.214^{*} \\
(.097)\end{array}$ \\
\hline Constant & 1.938 & 1.948 & 3.329 & 3.144 & 2.905 \\
\hline & .222 & .188 & .075 & .030 & .033 \\
\hline$n$ & 483 & 372 & 482 & 365 & 517 \\
\hline
\end{tabular}

Note: Standardized regression coefficients are in parentheses.

${ }^{*} p<.05 .{ }^{* * *} p<.001$.

cupy. The other, more atypical group of downwardly mobile sons slip from modest to even more marginal socioeconomic positions and may be more than usually dependent on the parents for material assistance. This may violate the parents' expectations and even strain the parents' resources, perhaps resulting in more restrained expressions of affection toward these children.

\section{DISCUSSION}

The findings reported here are subject to the limitations of a geographically restricted sample of older parents and a selective group of their adult children. Although there is no evident reason to consider the results as unique to this sample, they are perhaps more valuable in illuminating how social mobility influences intergenerational family dynamics than in precisely gauging the magnitude and breadth of its impact. The mobility effects uncovered here do not reveal a single transparent pattern, but possibly several. The influence of mobility is scattered across a range of intergenerational interactions, perceptions, and feelings, but is unrelated to many others. Moreover, each of these effects is quite specific to the gender of the child and/or to one direction in which mobility may occur.

The effects of mobility on family relations are generally rather modest. Although most of the children in the study are upwardly or downwardly mobile to some degree, mobility accounts for a small amount of the variation in intergenerational outcomes. Nevertheless, these mobility effects are not vitiated by the addition of other influential factors-proximity, family size, gender, marital status, and parental disability-into the explanatory models. With the exception of proximity, the magnitude of the influence of mobility is similar to that of these other variables. Proximity exerts an enormous influence on behavioral outcomes like visiting and household help but is usually an insignificant factor in the feelings and perceptions expressed by parents and children toward one another. Further, differences in residential proximity between mobile and nonmobile children and their parents do not account for the mobility effects demonstrated here.

Perhaps of greater interest than their individual significance is the apparent patterning of these mobility effects and how they may reflect family 
TABLE 6. Regression of Child's and Parent's Expressed Affection for ONe Another

\begin{tabular}{|c|c|c|c|c|}
\hline \multirow[b]{2}{*}{ Predictor Variables } & \multicolumn{2}{|c|}{$\begin{array}{c}\text { Child's Affection } \\
\text { for Parent }\end{array}$} & \multicolumn{2}{|c|}{$\begin{array}{l}\text { Parent's Affection } \\
\text { for Child }\end{array}$} \\
\hline & Daughters Only & Sons Only & Daughters Only & Sons Only \\
\hline Parent's SEI & $\begin{array}{l}-.002 \\
(-.082)\end{array}$ & $\begin{array}{l}-.008^{*} \\
(-.239)\end{array}$ & $\begin{array}{l}.0002 \\
(.012)\end{array}$ & $\begin{array}{l}.001 \\
(.077)\end{array}$ \\
\hline Extent of downward mobility & $\begin{array}{l}-.001 \\
(-.019)\end{array}$ & $\begin{array}{l}.014^{* *} \\
(.220)\end{array}$ & $\begin{array}{l}.005 \\
(.177)\end{array}$ & $\begin{array}{l}.005 \\
(.144)\end{array}$ \\
\hline Extent of upward mobility & $\begin{array}{l}-.002 \\
(-.062)\end{array}$ & $\begin{array}{l}-.002 \\
(-.060)\end{array}$ & $\begin{array}{c}.001 \\
(-.051)\end{array}$ & $\begin{array}{l}-.001 \\
(-.060)\end{array}$ \\
\hline $\begin{array}{l}\text { Extent of downward mobility } \\
\text { from low origins }\end{array}$ & & & $\begin{array}{l}-.0002^{*} \\
(-.191)\end{array}$ & $\begin{array}{l}-.0002^{*} \\
(-.238)\end{array}$ \\
\hline Residential separation & $\begin{array}{l}-.022 \\
(-.071)\end{array}$ & $\begin{array}{l}-.006 \\
(-.016)\end{array}$ & $\begin{array}{l}-.005 \\
(-.025)\end{array}$ & $\begin{array}{c}-.001 \\
(-.003)\end{array}$ \\
\hline Parental disability & $\begin{array}{l}.034^{* *} \\
(.155)\end{array}$ & $\begin{array}{l}.025 \\
(.091)\end{array}$ & $\begin{array}{l}-.008 \\
(-.062)\end{array}$ & $\begin{array}{l}.003 \\
(.019)\end{array}$ \\
\hline Number of parent's living children & $\begin{array}{l}.026 \\
(.055)\end{array}$ & $\begin{array}{l}.058 \\
(.096)\end{array}$ & $\begin{array}{l}.025 \\
(.089)\end{array}$ & $\begin{array}{l}.006 \\
(.021)\end{array}$ \\
\hline Parent married versus unmarried & $\begin{array}{l}.177^{*} \\
(.132)\end{array}$ & $\begin{array}{l}.014 \\
(.009)\end{array}$ & $\begin{array}{l}.039 \\
(.051)\end{array}$ & $\begin{array}{l}-.030 \\
(-.039)\end{array}$ \\
\hline Parent female versus male & $\begin{array}{l}-.049 \\
(-.034)\end{array}$ & $\begin{array}{c}-.014 \\
(-.009)\end{array}$ & $\begin{array}{l}.034 \\
(.042)\end{array}$ & $\begin{array}{l}-.002 \\
(-.003)\end{array}$ \\
\hline Child married versus unmarried & $\begin{array}{l}.152 \\
(.101)\end{array}$ & $\begin{array}{l}.314^{*} \\
(.165)\end{array}$ & $\begin{array}{l}.076 \\
(.089)\end{array}$ & $\begin{array}{l}.046 \\
(.049)\end{array}$ \\
\hline $\begin{array}{l}\text { Constant } \\
R^{2} \\
n\end{array}$ & $\begin{array}{r}2.404 \\
.070 \\
325\end{array}$ & $\begin{array}{r}2.218 \\
.104 \\
193\end{array}$ & $\begin{array}{r}2.740 \\
.034 \\
482\end{array}$ & $\begin{array}{r}2.804 \\
.032 \\
371\end{array}$ \\
\hline
\end{tabular}

Note: Standardized regression coefficients are in parentheses.

${ }^{*} p<.05 .{ }^{* *} p<.01$.

dynamics. One regularlity among the findings is that, with one exception, mobility influences feelings and perceptions but not behavior. Mobility is unrelated to visiting and the level of household assistance provided by children to older parents. The one behavioral exception-the diminished involvement of downwardly mobile sons in sociable interactions with their parents-may reflect the parents' desire to be or to appear to be less involved with the child.

The findings are generally consistent with prior studies discounting effects on the rates of familial interaction but suggesting that "stressful emotional relationships, tensions and parent-child estrangement [are] associated with actual or anticipated mobility" (Kessin, 1971: 17). The cur- rent study departs from those before it in that the perspectives of both mobile children and their parents have been examined, not one or the other. This is crucial to uncovering the dynamics that social mobility may introduce into family relations, because whatever "estrangement" occurs is apparently not mutual, but confined to the perspective of the parent or child occupying the superior status position.

One way families can cope with divergent class positions is through "prestige identification" (Turner, 1970), enhancing one's own prestige through a form of "status by association" (Litwak, 1960). This may explain why downwardly mobile children, although their style of living is likely to be less splendid than that of their parents,

TABle 7. Percentage of Children Reporting They Received Household Assistance and Emotional Support from Their Parents in the Last Six Months, by Parent's Occupational Status and Soclal Mobility OF THE CHILD

\begin{tabular}{llccc}
\hline \hline \multirow{2}{*}{ Parent's Occupation } & \multicolumn{2}{c}{$\begin{array}{c}\text { Receiving } \\
\text { Household Assistance }\end{array}$} & $\begin{array}{c}\text { Receiving } \\
\text { Emotional Support }\end{array}$ & $n$ \\
\hline \multirow{3}{*}{ Blue collar } & Child's Mobility & $66.7 \%$ & $33.3 \%$ & 18 \\
& Downwardly mobile & 15.6 & 46.9 & 32 \\
& Nonmobile & 19.6 & 32.9 & 143 \\
\hline \multirow{3}{*}{ White collar } & Upwardly mobile & 11.5 & 51.0 & 104 \\
& Downwardly mobile & 14.0 & 42.1 & 107 \\
& Nonmobile & 19.1 & 47.9 & 94 \\
\hline
\end{tabular}


do not report any special lifestyle divergences from their parents. The logic behind this explanation can be reversed, however. Those who are subordinate may bask in the reflection of the superordinate, but the superior risks status dimunition through this association. Higherstatus parents may avoid the status "contamination" by describing their downwardly mobile sons as less socially involved with the parents and more divergent in lifestyle.

At the same time, the enhanced affection of downwardly mobile sons for their parents may follow from their attachment to the parents for a sense of preserved status in the face of a socioeconomic slide. Parents do not reciprocate in kind, and those from modest socioeconomic backgrounds themselves actually express more reserved feelings of love toward their downwardly mobile children. These family situations, although rare and atypical, may engender dynamics that are linked to highly specific forms of filial dependency. In a similiar examination of the effects of social mobility, Adams (1968) concluded that downwardly mobile children receive more tangible aid and emotional assistance from their parents than they return to them. The current findings suggest that the nature of dependency is contingent on the parent's status. The majority of downwardly mobile sons come from white-collar backgrounds and are especially likely to identify their parents as sources of emotional support after they slip into the blue-collar world. The small group of downwardly mobile children who have fallen in status below their parents' working-class positions are most likely to report that their parents provide direct services to the child's household. For downwardly mobile sons who land in very marginal economic positions, this may represent a violation of household and financial autonomy between the generations, a violation reflected in the parents' feelings toward the child. For downwardly mobile sons with whitecollar origins, the emotional support received from parents is coupled with more unqualified affection toward the parent.

The processes of status enhancement or dimunition by association are more clearly suggested for mobile sons and their parents than for mobile daughters. Occupational status may be more acutely assessed and compared for mobile sons than daughters, whose status may be seen as "borrowed" from their husbands, especially among older cohorts. Like sons, upwardly mobile daughters tend to view their parent's lifestyle as divergent from their own. Unlike the sons, however, upwardly mobile daughters are alone in reporting that they consider the services they pro- vide to their parents especially burdensome. This is not so much an expression of embittered resentment as an acknowledgement of spent time and energy. These daughters may never have abandoned cultural expectations to "honor thy father and mother," but they may be more conscious of them when they emerge in the parents' more needy later life. Perhaps after moving to a different cultural and social plane, either through their own or their husbands' occupational advancement, these daughters are made more aware of the escalating demands and needs of their parents. The disabilities and increasing dependency of aging parents may replace choice with obligation as the foundation of some parent-child interactions, a change that upwardly mobile daughters may more readily acknowledge as a sacrifice for themselves.

Of the several models used to test for mobility effects, no one model emerges as generally preferred. When we examine this particular substantive area, some models appear to be more useful than others. Because the mobility effects here are limited to either the extent of upward mobility or of downward mobility, Duncan's square additive model, which does not allow these parameters to be introduced separately, may fail to detect the effects. Hope's diamond additive model, on the other hand, might fail to accurately capture the class effects, which were limited in most instances to class of origin, because it averages class of origin and class of destination. Sobel's diagonal model is acceptable when both class origins and destinations are significant factors, but it requires a very complicated estimation procedure, particularly when class origins and class destinations do not exert equal influences. Our results indicate that the assumption of acculturation underlying each of these models - that both class origins and destinations are significant factors that must be controlled in the model-does not always obtain, and that simpler models that include both the significant class parameter and the theoretically relevant mobility parameters can be employed with productive results.

\section{FOOTNOTES}

1. For additional details regarding the sample, see Litwak (1985).

2. Occupational status is gauged by utilizing the updated SEI for use with the 1970 U.S. Census Bureau classification of occupational titles (Hauser and Featherman, 1977) 
3. Duncan's square addition model takes the form:

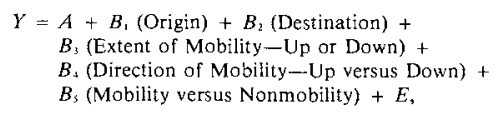

where extent of mobility is the absolute value of destination minus origin and the other mobility parameters are dummy variable contrasts. Hope's diamond additive model can be rendered as:

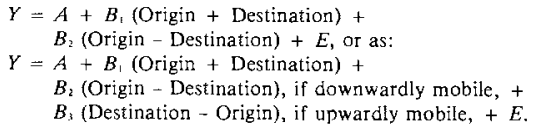

Sobel's diagonal model is like the latter, except that it expresses the class effects as increments or decrements equal to those characterizing the nonmobile in one's class of origin and the nonmobile in one's class of destination.

4. Origin and destination cannot be included along with separate parameters for the extent of upward and downward mobility without overidentifying the model. Because of this definitional dependence of the interactive mobility effects upon the main class effects, the larger the net cast for one, the less is the remaining catch for the other. Class is used here to designate any socioeconomic stratum.

5. For example, the constraint of overidentification causes Duncan to include mobility parameters of questionable theoretical relevance, such as the extent of mobility irrespective of its direction, and leads Hope to include an ambiguous class parameter, the average of class of origin and class of destination.

6. In the analyses of each of these dependent variables, we first estimated the Duncan square additive model and the Hope diamond additive model, which consistently reported no significant mobility effects. The Duncan model, and a separate analysis of the effects of class origin and class destination on the dependent variables, indicated that class destination was also an insignificant factor. In order to remove class destination from the model, we further ensured that its inclusion in the model as a control fails to substantially alter the estimates for the effects of the other in dependent variables, including the mobility effects. In the following analyses where destination is dropped, the standardized regression coefficients for the significant independent variables do not appreciably change when class destination is reentered into the model and the nonsignificant mobility parameter is dropped in turn.

7. This analysis requires two stages of estimation, only the latter of which appears in the table. The first stage estimates the class effect (SEI) through a regression analysis restricted to the nonmobile intergenerational pairs. Following Kessin's (1971) procedure, the nonmobile are those where the difference between parent and child SEI scores is less than half the standard deviation of the absolute value of the discrepancies in SEI for all pairs. This cutoff designates about one quarter of the sample as nonmobile. With the use of the regression coefficients that result, the dependent variable values of every case, mobile and stable, are transformed to remove the estimated effect on the dependent variable predicted for nonmobile respondents at identical parent and child SEI positions. These transformed scores are regressed on mobility parameters in the second stage.

\section{REFERENCES}

Adams, Bert N. 1968. Kinship in an Urban Setting. Chicago: Markham.

Adams, Bert N. 1970. "Isolation, function and beyond: American kinship in the 1960's." Journal of Marriage and the Family 32: 575-597.

$\rightarrow$ Aiken, Michael, and David Goldberg. 1969. "Social mobility and kinship: A re-examination of the hypothesis." American Anthropologist 71: 261-269.

Blau, Peter M. 1956. "Social mobility and interpersonal relations." American Sociological Review 21: 290-295.

Clark, Margaret, and Barbara G. Anderson. 1967, Culture and Aging. Springfield, IL: Charles C Thomas.

$\rightarrow$ Davis, Kingsley. 1940. "The sociology of parent-youth conflict.' American Sociological Review 5: 523-535.

Dumont, Arsène. 1890. Depopulation et Civilisation [Population Decline and Civilization]. Paris.

Duncan, Otis D. 1961. "A socioeconomic index for all occupations.” Pp. 109-138 in A. Reiss, Jr. (ed.), Occupations and Social Status. New York: Free Press.

Duncan, Otis D. 1966. "Methodological issues in the analysis of social mobility." Pp. 51-97 in N. Smelser and S. M. Lipset (eds.), Social Structure and Mobility in Economic Development. Chicago: Aldine.

Durkheim, Emile. 1951. Suicide. New York: Free Press, (Original work published in 1897.)

$\rightarrow$ Halaby, Charles N., and Michael E. Sobel. 1979. "Mobility effects in the workplace." American Journal of Sociology 85: 385-416.

Hauser, Robert M., and David L. Featherman. 1977. The Process of Stratification: Trends and Analyses. New York: Academic Press.

Hope, Keith. 1975. "Models of status inconsistency and social mobility effects." American Sociological Review 40: 322-343.

Kessin, Kenneth. 1971. "Social and psychological consequences of intergenerational occupational mobility." American Journal of Sociology 77: 1-18.

Klatzky, Sheila R. 1972. Patterns of Contact with Relatives. Rose Monograph Series in Sociology. Washington, DC: American Sociological Association.

Lee, Gary R. 1980. "Kinship in the seventies: A decade review of research and theory." Journal of Marriage and the Family 42: 923-934.

$\rightarrow$ Litwak, Eugene. 1960. "Occupational mobility and extended family cohesion." American Sociological Review 25: 9-21. 
Litwak, Eugene. 1985. Helping the Elderly: The Complementary Roles of Informal Networks and Formal Systems. New York: Guilford Press.

$\rightarrow$ Locke, Harvey J. 1940. "Mobility and family disorganization." American Sociological Review 5: 489-494.

Parsons, Talcott. 1959. "The social structure of the family." Pp. 241-274 in Ruth Anshen (ed.), The Family: Its Function and Destiny. New York: Harper.

Schneider, David M., and George C. Homans. 1955. "Kinship terminology and the American kinship system." American Anthropologist 57: 1194-1208.

Simos, Bertha G. 1970. "Relations of adults with aging parents." Gerontologist 10: 135-139.

$\rightarrow$ Sobel, Michael E. 1981. "Diagonal mobility models: A substantively motivated class of designs for the analysis of mobility effects." American Sociological Review 46: 893-906.

Sobel, Michael E. 1984. "Social mobility and fertility revisited: Some new models for the analysis of the mobility effects hypothesis." Paper presented at the 1984 annual meeting of the American Sociological Association, San Antonio, August.

Sorokin, Pitirim. 1927. Social Mobility. New York: Harper.

Troll, Lillian E., Sheila J. Miller, and Robert C. Atchley. 1979. Families in Later Life. Belmont, CA: Wadsworth.

Turner, Ralph. 1970. Family Interaction, New York: Wiley.

\section{APPENDIX}

\section{Operational Definitions, Means, and Standard DeVIatrons of DePENDENT VARIABLES}

1. Visiting frequency: Natural log of the number of annual parent-child visits; parent's report. (Mean $=3.1 ; S D=2.3$ )

2. Household services provided by the children: Parent's report of the number of the following services provided in the previous six months: light housekeeping, laundry, money management, small household repairs. $($ Mean $=1.0 ; S D=1.4)$

3. Sense of sacrifice: Child's report that assistance to the parent entails major/considerable (3), minor (2), or no (1) sacrifice for the child and his/her family. (Mean $=1.6 ; S D=0.8$ )

4. Sociable activities: Parent's report of the child's involvement within the previous six months in joint contacts with other relatives, shared meals with the parent, and small gifts given to the parent. $($ Mean $=1.5 ; S D=1.2$ )

5. Lifestyle similarity: Parent and child reports of whether their lifestyle is like the other's all (5), most (4), half (3), some (2), or none (1) of the time.

Parent's report $($ Mean $=3.2 ; S D=1.1)$

Child's report (Mean $=2.8 ; S D=1.1$ )

6. Affection: Parent and child reports of whether they have feelings of love and affection for the other all (3), most (2), or some/little/none (1) of the time.

Parent's report $($ Mean $=2.9 ; S D=0.4)$

Child's report $\quad($ Mean $=2.4 ; S D=0.7)$ 